DOI: $10.4274 /$ turkderm.galenos.2021.60490

Turkderm-Turk Arch Dermatol Venereol 2021;55:130-4

\title{
Prevalence and clinical spectrum of childhood leprosy in a tertiary care hospital in Kolar
}

\author{
Kolar'daki üçüncü basamak hastanede pediatrik lepra prevalansı ve klinik
} spektrumu

\section{Naveena Gvl, ๑ Suresh Kumar Kuppuswamy, ๑ Rajashekar Talari Srinivas, ه Hanumanthayya Keloji}

Sri Devaraj Urs Academy of Higher Education and Research, Department of Dermatology, Venereology and Leprosy, Kolar, India

\begin{abstract}
Background and Design: Leprosy is a chronic granulomatous, infectious disease that primarily affects the skin and peripheral nerves. Leprosy in children is an indicator of active transmission in the community. This study aimed to analyze the prevalence and clinical spectrum of childhood leprosy and highlight the importance of examining close contacts and the impact of detection and treatment of leprosy in the community. Materials and Methods: This retrospective study included patients presenting to the dermatology department of a tertiary care hospital attached to a medical college during the years 2011-2019.

Results: Two hundred and twenty-three patients with leprosy were analyzed, of which 201 were adults and 22 were children. Children constituted $9.87 \%$ of the patients (approx. one child with leprosy for every 10 adults with leprosy). Of 22 children with leprosy, 13 (59.09\%) were boys and nine (40.90\%) were girls, with a ratio of 1.4:1. Twelve of twenty-two child patients (54.54\%) had a single patch, while 10 of $22(45.45 \%)$ had more than one skin lesion. Fourteen patients (63.63\%) were diagnosed clinically with borderline tuberculoid (BT) leprosy, and six patients (27.27\%) had borderline lepromatous leprosy. Of the fourteen patients with BT leprosy, 10 patients (71.4\%) had a single lesion. Eleven patients (50\%) were diagnosed with multibacillary leprosy, and eleven patients (50\%) were diagnosed with paucibacillary leprosy. A clinicopathological correlation was noted in 16 patients $(72.72 \%)$. Family contact was observed in four children with leprosy.

Conclusion: A high proportion of childhood leprosy cases indicates active transmission and warrants awareness among the community members and healthcare workers in terms of early detection and treatment of childhood and adult leprosy. This helps in preventing transmission, development of grave deformities, and associated social stigma of leprosy among the community members.

Keywords: Childhood leprosy, deformities, transmission
\end{abstract}

\section{Öz}

Amaç: Lepra, esas olarak deriyi ve periferik sinirleri etkileyen kronik granülomatöz, bulaşıcı bir hastalıktır. Pediatrik lepra, toplumdaki aktif bulaşmanın bir göstergesidir. Çalışmanın amacı, pediatrik lepranın yaygınlığını ve klinik spektrumunu analiz etmek, yakın temasların incelenmesinin önemini ve toplumda lepranın tespiti ve tedavisinin etkisini vurgulamaktır.

Gereç ve Yöntem: Bu retrospektif çalışma, 2011-2019 yılları arasında tıp fakültesine bağlı üçüncü basamak bir hastanenin dermatoloji bölümünde gerçekleştirildi.

Bulgular: Toplam 223 lepra olgusu analiz edildi, bunların 201'i yetişkin lepra olgusu ve 22'si pediatrik lepra olgusuydu. Pediatrik lepra oranı $\% 9,87$ idi. (her 10 yetişkin lepra olgusu için yaklaşık 1 pediatrik lepra olgusu). Yirmi iki pediatrik lepra olgusundan, 13'ü (\%59,09) erkek, 9'u (\%40,90) kızdı. Erkek: Kız oranı 1,4:1 idi, \%54,54'te (22 hastanın 12'si) tek yama vardı, \%45,45'inde (22 hastanın 10'u) birden fazla deri lezyonu vardı. On dört hasta $(\% 63,63)$ klinik olarak borderline tüberküloit $(B T)$ lepra tanısı almışı ve altı hastada $(\% 27,27)$ borderline

Address for Correspondence/Yazışma Adresi: Suresh Kumar Kuppuswamy MD, Sri Devaraj Urs Academy of Higher Education and Research, Department of Dermatology, Venereology and Leprosy, Kolar, India

Phone: +8686900404 E-mail: dr.sk5787@gmail.com Received/Geliș Tarihi: 17.12.2020 Accepted/Kabul Tarihi: 10.03.2021 ORCID: orcid.org/0000-0001-5988-2800

Cite this article as: Gvl N, Kuppuswamy SK, Srinivas RT, Keloji H. Prevalence and clinical spectrum of childhood leprosy in a tertiary care hospital in Kolar. Turkderm-Turk Arch Dermatol Venereol 2021;55:130-4.

(c) Copyright 2021 by Turkish Society of Dermatology and Venereology

Turkderm - Turkish Archives of Dermatology and Venereology published by Galenos Yayınevi. 
lepromatous lepra vardı. On dört BT lepra hastasından 10'unda $(\% 71,4)$ tek lezyon vardı. On bir $(\% 50)$ olgu multibasiller, on bir $(\% 50)$ olgu paucibacillary idi. Klinikopatolojik korelasyon $16(\% 72,72)$ hasta arasında görüldü. Aile teması (bulaşı) 4 pediatrik lepra olgusunda görüldü.

Sonuç: Pediatrik lepra olgularının yüksek oranı, aktif bulaşma olduğunu gösterir ve toplum üyeleri ile sağlık çalışanları arasında pediatrik ve erişkin leprasının erken teşhisi ve tedavisi konusunda farkındalık sağlar. Bu, topluluk üyeleri arasında yayılımın, ciddi deformitelerin gelişmesinin ve lepra ilişkili sosyal damgalanmanın önlenmesine yardımcı olur.

Anahtar Kelimeler: Pediatrik lepra, deformiteler, iletim

\section{Introduction}

Leprosy is a chronic disease that primarily involves the skin and peripheral nerves ${ }^{1}$. According to the National Leprosy Eradication Program 2018$2019,120,334$ new patients with leprosy were detected in India during the period of 2018-2019, and the annual new case detection rate is 8.7 per 100,000 population. The proportion of childhood cases reported in our country was $7.7 \%^{2}$. The annual new case detection rate in Karnataka, India, is 3.8 per 100,000 population ${ }^{2}$. Though, in 2005, leprosy was declared eliminated by the World Health Organization (WHO), it is still an endemic disease in various countries ${ }^{3}$. Leprosy in children is an indicator of active community transmission. Close contacts could be the infection source whether it is familial or non-familial ${ }^{3}$. Childhood leprosy cases in the community evidently indicate the grave nature of the problem of undetected adult leprosy and its deformities and active transmission and highlight the implications on individual patients and the community ${ }^{4,5}$.

\section{Materials and Methods}

All patients up to the age of 18 years who presented to dermatology, venereology, and leprosy department in a tertiary care setting, R.L Jalappa Hospital, Kolar attached to a medical college during January 2011 to December 2019 and were diagnosed with leprosy were included in the study. All patients were diagnosed based on a detailed history and clinical examination, followed by slit skin smear and skin biopsy. Retrospective data were collected from the records maintained in the leprosy clinic of the hospital from January 2011 to December 2019. Familial contact history was also noted. Patients were diagnosed clinically using Ridley-Jopling classification. Based on the number of skin lesions, peripheral nerve involvement, and smear positivity, the patients were categorized as multibacillary (MB) or paucibacillary (PB) for therapeutic purposes. In cases of lepra reactions, patients were treated accordingly with glucocorticoids, non-steroidal anti-inflammatory drugs, zinc, and multivitamins, along with supportive therapy. All patients had monthly follow-ups until the completion of the therapy, and thereafter, they had six-month follow-ups.

This study is approved by the Institutional Ethical Review Committee of Sri Devaraj Urs Academy of Higher Education and Research, Kolar (approval number: SDUMC/KLR/IEC/305/2019-20, date: 21.04.2020).

\section{Statistical Analysis}

Data was entered into Microsoft excel data sheet and was analyzed using SPSS Version 22.0 software. The data was analyzed for descriptive statistical analysis using frequencies and proportions. Anonymity of the respondents at every stage of data analysis was maintained.

\section{Results}

Two hundred and twenty-three patients were diagnosed with leprosy during the study period of January 2011 to December 2019, of which
201 were adults and 22 were children (0-18 years old) (Table 1). Children constituted $9.87 \%$ of the patients (approx. one child with leprosy for every 10 adults with leprosy). Of 22 children with leprosy, 13 (59.09\%) were boys and nine (40.90\%) were girls (Table 2), with a ratio of 1.4:1. Twelve of twenty-two child patients (54.54\%) had a single patch, while 10 of $22(45.45 \%)$ had more than one skin lesion (Figure 1). Fourteen patients $(63.63 \%)$ were diagnosed with borderline tuberculoid (BT) leprosy, of which 10 had a single lesion. Six patients $(27.27 \%)$ had borderline lepromatous leprosy. One patient had borderline borderline leprosy (4.5\%) and another patient had indeterminate leprosy (4.5\%). A clinicopathological correlation was noted in 16 patients (72.72\%) (Table 3) and in nine of ten patients clinically diagnosed with BT. Deformity was seen in two patients (9\%): One patient had a partial right claw hand, and the other had a bilateral claw hand. A trophic ulcer over the ball of the right great toe was noticed in one patient (4.5\%). Lepra reactions were seen in two patients (9\%), where both

Table 1. Total number of adult and child patients with
leprosy
\begin{tabular}{|l|l|l|l|}
\hline SI. no. & Type & Number of patients & Percentage \\
\hline 1 & Adult leprosy & 201 & $90 \%$ \\
\hline 2 & Childhood leprosy & 21 & $10 \%$ \\
\hline
\end{tabular}

\section{Table 2. Total number of boys and girls with childhood} leprosy

\begin{tabular}{|l|l|l|l|}
\hline SI. no. & Gender & Number of patients & Percentage \\
\hline 1 & Male & 13 & $59.09 \%$ \\
\hline 2 & Female & 9 & $40.09 \%$ \\
\hline
\end{tabular}

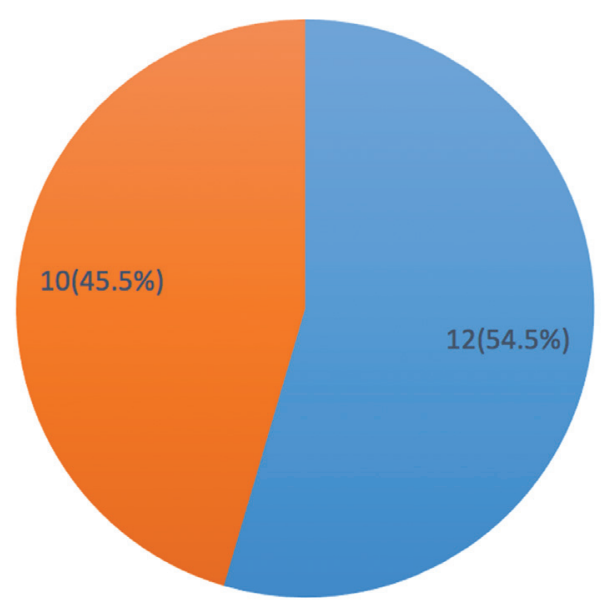

- Single lesion $\quad>$ One lesion

Figure 1. Total number of patches 
had type 1 reaction. Familial contact history was noted in four of 22 patients (18.18\%) (Table 4). In the first patient, the familial contact was presented in the father, and in the second and third patients were siblings, and the familial contact was their grandfather. In the fourth patients, the familial contact was the uncle. Of 10 patients who had more than one skin lesion, four patients (18.1\%) had a positive slit skin smear test (Table 5). Slit skin smear test was negative in 18 patients (81.9\%). Eleven patients (50\%) were MB, and eleven patients (50\%) were $\mathrm{PB}$, according to the WHO classification (Table 6)

\section{Discussion}

Leprosy, or Hansen's disease, is a chronic, granulomatous, infectious disease that primarily affects the skin and peripheral nerves ${ }^{1}$. It has variable clinical manifestations based on the cell-mediated immunity of the particular host. The widely accepted classification is RidleyJopling classification, as it includes the clinical, histopathological, and immunological spectrum of the disease ${ }^{6}$. The WHO categorized leprosy into two types, for field healthcare workers: $\mathrm{MB}$ and $\mathrm{PB}^{7}$. The Indian leprosy classification has considered pure neuritic variant as a separate group ${ }^{3}$.

Leprosy affects all ages from early infancy to old age ${ }^{8}$. In our study, 22 child patients were diagnosed with leprosy. The mean age of patients was 13.1 years, with the eldest being 18 years old and the youngest being six years old. This relatively older age of onset could be due to a long incubation period, late diagnosis of lesions, and difficulty while assessing the loss of sensations in very young age groups ${ }^{8}$. Delayed diagnosis will lead to deformities and disabilities, which have a significant impact on the psychosocial, physical and financial aspects of these children and their families ${ }^{8}$. Low socioeconomic status, illiteracy, and ignorance about the disease will lead to leprosy-related deformities ${ }^{9}$. A child with leprosy-related deformity bears the stigma for life ${ }^{10}$.

In this study, boys outnumbered girls $(1.4: 1)$, which was in concordance with other studies by Katakam et al. ${ }^{1}$, Chhabra et al. ${ }^{11}$, and Adil et al. ${ }^{12}$. This increased incidence of leprosy in boys might be due to the greater mobility and accessibility to healthcare and neglecting the girl child ${ }^{1,11,12}$

Deformities were seen in two patients (9\%): One patient had a right claw hand, and the other had a bilateral claw hand. A trophic ulcer over the ball of the right great toe was seen in one patient (4.5\%). Residual deformity is the dreaded complication in children with leprosy, as it persists lifelong. Multiple skin lesions, older age, MB leprosy, multiple nerve involvement, smear positivity, reactions at presentation, thickened nerve trunks, and delay in seeking healthcare are the common risk factors for deformity development in children ${ }^{10}$.

Lepra reactions were seen in two patients (9\%), where both had type 1 reaction. Repeated reactions in children lead to psychological stress, deformity, and economic burden on the child's family ${ }^{10}$.

In our study, BT (63.6\%) was the most common type of leprosy. Similar results were shown by Palit and Inamadar ${ }^{9}$, Semwal et al. ${ }^{13}$,

\section{Table 3. Clinicopathological correlation}

\begin{tabular}{|l|l|l|l|l|l|}
\hline SI. no. & Age in years & Sex & Clinical diagnosis & $\begin{array}{l}\text { Histopathological } \\
\text { diagnosis }\end{array}$ & $\begin{array}{l}\text { Clinicopathological } \\
\text { correlation }\end{array}$ \\
\hline 1 & 14 & M & BT & BT & Yes \\
\hline 2 & 12 & M & BT & BT & Yes \\
\hline 3 & 8 & F & BT & BT & Yes \\
\hline 4 & 12 & M & BL & BL & Yes \\
\hline 5 & 14 & M & BT & BB & No \\
\hline 6 & 8 & M & Indeterminate & BT & No \\
\hline 7 & 12 & M & BT & BT & Yes \\
\hline 8 & 19 & M & BT & BT & Yes \\
\hline 9 & 15 & M & BT & BT & Yes \\
\hline 10 & 9 & M & Indeterminate & Indeterminate & Yes \\
\hline 11 & 6 & F & Indeterminate & BT & No \\
\hline 12 & F & BT & BT & Yes \\
\hline 13 & 10 & F & Indeterminate & BT & No \\
\hline 14 & 16 & F & BL & BL & No \\
\hline 15 & 13 & M & Indeterminate & BT & Yes \\
\hline 16 & 14 & M & BL & BL & Yes \\
\hline 17 & 17 & F & BL & BL & Yes \\
\hline 18 & 16 & M & BL & BL & Yes \\
\hline 19 & 12 & F & BT & BT & Yes \\
\hline 20 & 16 & M & BL & BL & Yes \\
\hline 21 & 15 & F & BT & BT & No \\
\hline 22 & 14 & F & BL & BT & \\
\hline M: Male, F: Female, BT: Borderline tuberculoid, BL: Borderline lepromatous, BB: Borderline borderline & & \\
\hline & & & & \\
\hline
\end{tabular}


Table 4. Number of patients with contact history and those with no contact history

\begin{tabular}{|l|l|l|l|}
\hline SI. no. & Type & Number of patients & Percentage \\
\hline 1 & Contact history & 4 & $18.18 \%$ \\
\hline 2 & Non-contact & 18 & $81.9 \%$ \\
\hline
\end{tabular}

Table 5. Number of patients with positive and negative slit skin smear tests

\begin{tabular}{|l|l|l|l|}
\hline SI. no. & Slit skin smear & Number of patients & Percentage \\
\hline 1 & Positive & 4 & $18.1 \%$ \\
\hline 2 & Negative & 18 & $81.9 \%$ \\
\hline
\end{tabular}

Table 6. Number of patients diagnosed with multibacillary and paucibacillary leprosy, according to the World Health Organization

\begin{tabular}{|l|l|l|l|}
\hline SI. no. & Type & Number of patients & Percentage \\
\hline 1 & MB & 11 & $50 \%$ \\
\hline 2 & PB & 11 & $50 \%$ \\
\hline \multicolumn{2}{|l}{ MB: Multibacillary, PB: Paucibacillary } \\
\hline
\end{tabular}

and Singal et al. ${ }^{14}$. A study by Sasidharanpillai et al. ${ }^{15}$ also showed the predominance of BT in their study.

Slit skin smear was positive in four cases (18.1\%), and previous studies by Grover et al. ${ }^{16}$ have reported higher smear positivity rates ranging from $17.4 \%$ to $30 \%$. Another study by Dogra et al. ${ }^{17}$ also reported slit skin smear positivity in $28.8 \%$ of the children.

A clinicopathological correlation was seen in 16 patients (72.2\%), which was in concordance with a study by Dogra et al. ${ }^{17}$ and Philip et al. ${ }^{18}$ and in 9 of 10 patients clinically diagnosed with borderline tuberculoid. One patient who was clinically diagnosed with borderline tuberculoid turned out to be borderline borderline histologically.

In our study, four patients (18.1\%) had a history of contact within the household, which was similar to other studies (Philip et al. ${ }^{18}$, and Shetty et al. ${ }^{19}$ ). It has been documented that the risk of a person developing leprosy is multiplied by four times with extrafamilial contact and multiplied by nine times with intrafamilial contact ${ }^{18,19}$. This indicates the high risk of transmission. Regular screening of contacts of patients, mainly children, should be done at periodic intervals. Screening school children can be considered an effective way to diagnose leprosy in childhood. In some developing countries, many leprosy cases will not be detected while conducting school surveys, as many of these children work for daily wages rather than going to the schools. House-to-house surveys and community-based detection of cases are better methods to detect leprosy cases in childhood ${ }^{10}$.

\section{Study Limitations}

This is a single centered retrospective study design. It is a hospital based study, therefore it does not represent the actual burden of leprosy in the community. Community based studies is need of the hour to know the actual incidence, prevalence and factors affecting the causation of leprosy.

\section{Conclusion}

The clinical, bacteriological, and histopathological characteristics of newly detected childhood leprosy cases in the community evidently indicate the grave nature of the problem of undetected and untreated adult leprosy and its deformities and active transmission. This warrants awareness among the community members and healthcare workers in terms of early diagnosis and treatment of childhood and adult leprosy. Early detection and treatment of childhood and adult leprosy prevent not only transmission among the community but also its grave deformities and associated social stigma. It also reflects on the impact of national programs in eradicating leprosy.

\section{Ethics}

Ethics Committee Approval: This study is approved by the Institutional Ethical Review Committee of Sri Devaraj Urs Academy of Higher Education and Research, Kolar (approval number: SDUMC/KLR/ IEC/305/2019-20, date: 21.04.2020).

Informed Consent: The study design is retrospective in nature and the data used for the study is obtained from the records maintained in the leprosy clinic. However, the anonymity of the respondents at every stage of data analysis was maintained.

Peer-review: Externally and internally peer-reviewed.

\section{Authorship Contributions}

Concept: N.G., S.K.K., R.T.S., H.K., Design: N.G., S.K.K., R.T.S., H.K., Data Collection or Processing: N.G., Analysis or Interpretation: N.G., Literature Search: N.G., S.K.K., Writing: S.K.K., R.T.S., H.K.

Conflict of Interest: No conflict of interest was declared by the authors.

Financial Disclosure: The authors declared that this study received no financial support.

\section{References}

1. Katakam BK, Netha GNR, Kavitha SB, Satyasri T, Singh R: Clinical, bacteriological and histopathological characteristics of leprosy in children in a tertiary care centre. Indian J Lepr 2018;90:269-75.

2. National Leprosy Eradication Programme Annual report for the year 20182019. Central Leprosy Division, Directorate General of Health Services, Ministry of Health and Family Welfare, Government of India, Nirman Bhawan, New Delhi-11001.

3. Pradhan S, Nayak BP, Dash G: Childhood leprosy: A review. Indian J Paediatr Dermatol 2019;20:112-6.

4. Babu A, Bhat MR, Jayaraman J: Childhood leprosy in post elimination era: A vision achieved or a Concern growing at large. Indian J Paediatr Dermatol 2018;19:26-30.

5. Ghunawat S, Relhan V, Mittal S, Sandhu J, Garg VK: Childhood leprosy: A retrospective descriptive study from Delhi. Indian J Dermatol 2018;63:455-8.

6. Ridley DS, Jopling WH: Classification of leprosy according to immunity. A five-group system. Int J Lepr Other Mycobact Dis 966;34:255-73.

7. Pardillo FE, Fajardo TT, Abalos RM, Scollard D, Gelber RH: Methods for the classification of leprosy for treatment purposes. Clin Infect Dis 2007;44:10969 .

8. Narang T, Kumar B: Leprosy in children. Indian J Paediatr Dermatol 2019;20:12-24.

9. Palit A, Inamadar AC: Childhood leprosy in India over the past two decades. Lepr Rev 2014;85:93-9.

10. Palit A, Indamar AC, Desai S, Sharma P: Childhood leprosy in the postelimination phase: data from a tertiary health care Hospital in the Karnataka state of south India. Lepr Rev 2014;85:85-92. 
11. Chhabra N, Grover C, Singal A, Bhattacharya SN, Kaur R: Leprosy scenario at a tertiary level hospital in Delhi: A 5-year retrospective study. Indian J Dermatol 2015;60:55-9.

12. Adil M, Amin SS, Mohtashim M, Mushtaq S, Alam M, Priya A: Clinicoepidemiological study of leprosy from a North Indian tertiary care hospital. Int J Res Dermatol 2018;4:518-21.

13. Semwal S, Joshi D, Goel G, Asati D, Kapoor N: Clinico-histological correlation in Hansen's disease: Three-year experience at a newly established tertiary care center in central India. Indian J Dermatol 2018;63:465-8.

14. Singal A, Sonthalia S, Pandhi D: Childhood leprosy in a tertiary-care hospital in Delhi, India: a reappraisal in the post-elimination era. Lepr Rev 2011;82:259-69.

15. Sasidharanpillai S, Binitha MP, Riyaz N, et al: Childhood leprosy: a retrospective descriptive study from Government Medical College, Kozhikode, Kerala, India. Lepr Rev 2014;85:100-10.
16. Grover C, Nanda S, Garg VK, Reddy BS: An epidemiologic study of childhood leprosy from Delhi. Pediatr Dermatol 2005;22:489-90.

17. Dogra S, Narang T, Khullar G, Kumar R, Saikia UN: Childhood leprosy through the post-leprosy-elimination era: a retrospective analysis of epidemiological and clinical characteristics of disease over eleven years from a tertiary care hospital in North India. Lepr Rev 2014;85:296-310.

18. Philip M, Samson JF, Ebenezer S: A Ten Year Study of Pediatric Leprosy Cases in a Tertiary Care Centre in South Kerala. Indian J Lepr 2018;90:95-99.

19. Shetty VP, Ghate SD, Wakade AV, Thakar UH, Thakur DV, D'souza E: Clinical, bacteriological, and histopathological characteristics of newly detected children with leprosy: a population based study in a defined rural and urban area of Maharashtra, Western India. Indian J Dermatol Venereol Leprol 2013;79:512-7. 